\title{
PENGARUH KONFLIK KERJA, KEPEMIMPINAN DAN LINGKUNGAN KERJA TERHADAP STRES KERJA PEGAWAI PD PASAR KOTA DENPASAR
}

\author{
Agrineh Kapitan ${ }^{1}$ \\ A. A. Sagung Kartika Dewi ${ }^{2}$ \\ ${ }^{1,2}$ Fakultas Ekonomi dan Bisnis Universitas Udayana, Bali, Indonesia \\ Email: nita.kapitan22@yahoo.com
}

\begin{abstract}
ABSTRAK
Sumber daya manusia merupakan penggerak jalannya perusahaan dan merupakan asset terpenting bagi perusahaan.Masalah stres kerja di dalam organisasi perusahaan menjadi gejala yang penting diamati sejak mulai timbulnya tuntutan untuk efisiensi di dalam pekerjaan.Tujuan penelitian ini adalah untuk menjelaskan pengaruh konflik kerja, kepemimpinan, serta lingkungan kerja terhadap stres kerja pada PD. Pasar Kota Denpasar Unit Pasar Badung. Populasi penelitian ini adalah seluruh karyawan di PD. Pasar Kota Denpasar Unit Pasar Badung. Pengambilan sampel dalam penelitian ini menggunakan teknik sampel jenuh atau sensus, dimana seluruh populasi penelitian akan dipilih menjadi sampel. Data yang dikumpulkan pada penelitian ini dilakukan analisis dengan memakai analisis regresi linear berganda.Hasil analisis menunjukkan bahwa Konflik kerja berpengaruh positif dan signifikan sedangkan kepemimpinan serta lingkungan kerja memiliki pengaruh negatif dan signifikan pada stress kerja karyawan di PD. Pasar Kota Denpasar Unit Pasar Badung.
\end{abstract}

Kata kunci : konflik kerja, kepemimpinan, lingkungan kerja, stres kerja.

\section{ABSTRACT}

Human resources are the driving force of the company and are the most important asset for the company. The purpose of this study was to explain the effect of work conflict, leadership, and work environment on work stress. The population of this study were all employees in PD. Denpasar Market Badung Market Unit. Sampling in this study using saturated sample or census techniques, where the entire study population will be selected until, so that the number of samples used in this study were 98 employees, excluding 2 leaders in PD. Denpasar City Market Badung Market Unit. Data collected in this study were analyzed using multiple linear regression analysis. The results of the analysis showed that the work conflict had a positive and significant effect while the leadership and work environment had a negative and significant influence on the work stress of employees in PD. Denpasar City Market Badung Market Unit.

Keyword : work conflict, leadership, work environment, work stress. 


\section{PENDAHULUAN}

Globalisasi menyebabkan setiap perusahaan harus dapat bertindak profesional untuk dapat mencapai tujuan berdasarkan fungsi-fungsi manajemen seperti perencanaan, pengorganisasian, pengarahan dan pengawasan.Semua fungsi manajemen tersebut diaplikasikan kedalam perusahaan melalui fungsi perusahaan yaitu fungsi keuangan, operasi, personalia dan pemasaran.Salah satu fungsi perusahaan yang diperhatikan adalah sumber daya manusia. Sumber daya manusia merupakan penggerak jalannya perusahaan dan merupakan aset terpenting bagi perusahaan.Persaingan dan tuntutan profesionalitas yang semakin tinggi menimbulkan banyaknya tekanan-tekanan yang harus dihadapi individu dalam lingkungan kerja.Tekanan yang timbul dan berlangsung terus menerus berpotensi menimbulkan kecemasan yang sering dialami oleh masyarakat dan angkatan kerja pada khususnya disebut stres.Stres kerja dasarnya merupakan tekanan yang diterima pegawai.

Faktor yang mempengaruhi dari stres kerja adalah beban kerja yang berlebihan, tekanan atau desakan waktu, feedback mengenai pelaksanaan kerja yang tak mencukupi, konflik antara pribadi dengan antar kelompok dan perbedaan diantara nilai- nilai organisasi sertapegawai.Perubahan dan persaingan yang terjadi tentu akan menimbulkan konflik baru yang akan dihadapi. Perubahan yang terjadi menimbulkan konflik yang tidak dapat dihindari oleh para pegawai.Konflik yang tidak terkendali pada diri pegawai dapat menimbulkan keadaan yang merugikan perusahaan(Robbins, 2014).Penelitian mengenai stres kerja yang dilaksanakan olehEdi Suhanto (2009) melalui judul Pengaruh Stres Kerja 
sertalklim Perusahaan pada Loyalitas kerja pegawai dengan Kepuasan Kerja Sebagai Variabel Intervening (Studi di Bank Internasional Indonesia). Hasil penelitian tersebut menyatakan bahwa stress kerja memiliki pengaruh negatifserta signifikan pada kepuasan kerja, iklim perusahaan memiliki pengaruh positifserta signifikan pada kepuasan kerja, serta kepuasan kerja bisamenjadi penurunan loyalitas kerja pegawai.

Kepemimpinan adalah suatu cara seseorang pemimpin mempengaruhi perilaku bawahan agar mau bekerja sama dan bekerja secara produktif untuk mencapai tujuan organisasi (Hasibuan, 2010:171). Dalam kepemimpinanada sebuah gagasan, bila tidak ada kepemimpinan sebuahperusahaan yaitu kumpulankumpulan orang serta mesin yang tak beraturan. Tidak ada kepemimpinan ataupunbimbingan, hubungandiantara tujuan seseorangserta tujuan perusahaan memungkinkan akan jadi tidak efektif. Keadaan ini dapat timbulnya situasi dimana perseorangan bekerja untuk mencapai tujuannya,sementara itu keseluruhan perusahaan menjadi tidak efisien dalam mencapai sasarannya.Lingkungan kerja perusahaan sangat penting diperhatikan manajemen untuk meningkatkan efektivitas kerja pagawai. Meskipin lingkungan kerja tidak melaksanakan proses produksi dalam suatu perusahaan, namun lingkungan kerja mempunyai pengaruh langsung terhadap para pegawai yang melaksanakan proses kerja di dalam aktivitas pekerjaannya.

Salah satu organisasi di Bali yang memiliki peran penting bagi kehidupan masyarakat luas adalah PD. Pasar Kota Denpasar Unit Pasar Badung. PD. Pasar Kota Denpasar Unit Pasar Badung termasuk dalam Unit PD Pasar Kota Denpasar. 
Pasar Badung merupakan pasar tradisional di Kota Denpasar yang melakukan operasi selama 24 jam sebagai jantung ekonomi masyarakat. Selain merupakan lokasi yang melakukan persiapanberagam bahan kebutuhan pokok, pasar juga jadi ruang interaksi antara masyarakat lokal dan pendatang.Pasar yang beroperasi selama 24 jam tersebut menyebabkan para pegawainya harus bekerja ekstra. Pasar Badung sendiri terdiri dari dua bagian yaitu Pasar Badung Siang dan Pasar Badung Malam yang masing - masing dipimpin oleh Divisi malam dan siang. Namun pegawai untuk divisipasar badung siang dan pasar badung malam adalah pegawai yang sama, sehingga pegawai Pasar Badung bekerja siang dan malam sesuai dengan jadwal tanpa libur kecuali pegawai administrasinya yang bekerja selama enam hari kerja.

Fenomena mengenai konflik kerja dimana beberapa pekerja tidak ada waktu untuk berlibur menimbulkankaryawanjadi kelelahan serta stres dalam pekerjaan. Selain itu fenomena dalam kepemimpinan organisasi dimana pemimpin PD Pasar Kota Denpasar kurang memperhatikan kebutuhan pegawai perihal gaya kepemimpinan. Gaya kepemimpinan yang kurang terorganisir menyebabkan beberapa hal harus dilaksanakan secara mendadak sehingga hasil kerja kurang maksimal. Saat hasil kerja kurang maksimal, pemimpin malah menyalahkan pegawai karena dianggap bekerja kurang giat.

Fenomena mengenai stres kerja dapat dilihat dari banyaknya pegawai yang mengeluhkan akan pekerjaan yang mereka lakukan sehari-hari. Masih banyak pedagang di pasar Badung yang berpikir secara tradisional dan tidak menuntut untuk dilakukan penataan ulang. Pasar Badung harus lebih sabar dalam memberi 
arahan dan informasi terkait penataan Pasar Badung.Selain itu fenomena lingkungan kerja unit Pasar Badung yang kurang higenis membuat beberapa karyawan merasakan stress kerja akibat harus menata pasar Badung agar terlihat lebih baik, sedangkan infrastruktur utama Pasar Badung belum sepenuhnya bisa beroperasi.

Perusahaan pasti memiliki perselisihan atau konflik merupakan suatu yang tidak dapat dihindari. Konflik dapat berpengaruh positif dan negatif. Konflik yang timbul bisa bersifat konstruktif dalam hal pengambilan keputusan yang terbaik untuk kepentingan perusahaan atau bisa bersifat desktruktif karena terjadi sikap menyimpang dari pegawai yang menyebabkan menurutnya kinerja perusahaan.

Berdasarkan hasil penelitian dari Adekunle (2014) dengan judul Impact of Employee Stress on Operational Risk Management menyatakan terhadap pengaruh dari konflik kerja dan stress kerja. Hal tersebut juga didukung oleh penelitian oleh Harlock (2013), Anuari dkk. (2017), Han dan Netra (2014)serta Hwang (2014) yang sama-sama menjelaskan bahwa terhadap pengaruh dari konflik kerja terhadap stress kerja.Stres disebut sebagai akibat dari konflik, atau konflik yang mengakibatkan stres. Konflik yang tidak dikelola dengan baik dan dibiarkan terus menerus akan menyebabkan stres pada pegawai. Berdasarkan fakta tersebut maka dapat dirumuskan hipotesa seperti berikut:

$\mathrm{H}_{1}$ : Terdapat pengaruh yang positif dan signifikan antara konflik kerja terhadap stres kerja pegawai pada PD. Pasar Kota Denpasar Unit Pasar Badung.

Kepemimpinan adalah satu diantara penentu arah didalam berkembangnyaorganisasi dimana gaya kepemimpinan seorang didalam mengelola perusahaan memiliki pengaruh pada stress kerja. Pemimpin yang 
menuntut pegawainyaagarmelaksanakan tugas didalam waktu yang singkat, pengawasan yang ketat serta tekanan yang tidak realistis dapat menimbulkan stress kerja pada karyawan (Robbins, 2014).

Berdasarkan hasil penelitian dari Danny (2013) dengan judul Kepemimpinan Dan Lingkungan Kerja Terhadap Stres Kerja Pada Restoran A\&W Di City Of Tomorrow Surabaya. Hasil penelitian tersebut menyatakan menyatakan terhadap pengaruh dari kualitas kepemimpinan terhadap stress kerja karyawan. Hal tersebut juga didukung oleh penelitian oleh Cheng (2013), Campbell (2015) dan Gordon (2014) yang sama-sama mejelaskan bahwa terdapat pengaruh dari kepemimpinan terhadap stress kerja.Berdasarkan fakta tersebut maka dapat dirumuskan hipotesa seperti berikut:

$\mathrm{H}_{2}$ : Terdapat pengaruh yang negatif dan signifikan antara kepemimpinan terhadap stres kerja pegawai pada PD. Pasar Kota Denpasar Unit Pasar Badung.

Lingkungan kerja dimana semua pegawai melakukan aktivitasnya baik didalam kantor maupun diluar kantor, sangat penting untuk diperhatikan oleh pihak perusahaan. Hal itu karena salah satu penyebab dari stres kerja adalah lingkungan yang tidak nyaman. Lingkungan kerja merupakan salah satu penyebab dari keberhasilan dalam melaksanakan suatu pekerjaan, karena lingkungan kerja dapat mempengaruhi pegawai.Lingkungan kerja merupakan salah satu faktor penyebab terjadinya stres kerja. Hal tersebut menjadikan interaksi yang sesuai antara karyawan dengan lingkungan kerja akan menghasilkan stres karyawan yang baik. Noordiansah (2016) dalam penelitiannya memperoleh hasil bahwa lingkungan kerja fisik dan non fisik mempunyai pengaruh signifikan terhadap 
stres kerja pegawai, maka diperlukan adanya pemenuhan fasilitas dalam lingkungan kerja suatu perusahaan agar pegawai dapat bekerja dengan baik serta tidak mudah mengalami stres kerja.

Berdasarkan hasil penelitian Christanto (2014) dengan judul Analisis Pelatihan Dan Lingkungan Kerja Di PT Wahana Kosmetika Indonesia. Hasil penelitian tersebut menyatakan menyatakan terhadap pengaruh dari kualitas lingkungan kerja terhadap stress kerja karyawan. Hal tersebut juga didukung oleh penelitian oleh Chuanbao (2015), Rizki dkk. (2016), Mangkuprawira (2014) dan Bagyono (2016) yang sama-sama mejelaskan bahwa terdapat pengaruh dari kualitas lingkungan kerja terhadap stress kerja. Berdasarkan fakta tersebut maka dapat dirumuskan hipotesa seperti berikut:

$\mathrm{H}_{3}$ : Terdapat pengaruh yang negatif dan signifikan antara lingkungan kerja terhadap stres kerja pegawai pada PD. Pasar Kota Denpasar Unit Pasar Badung.

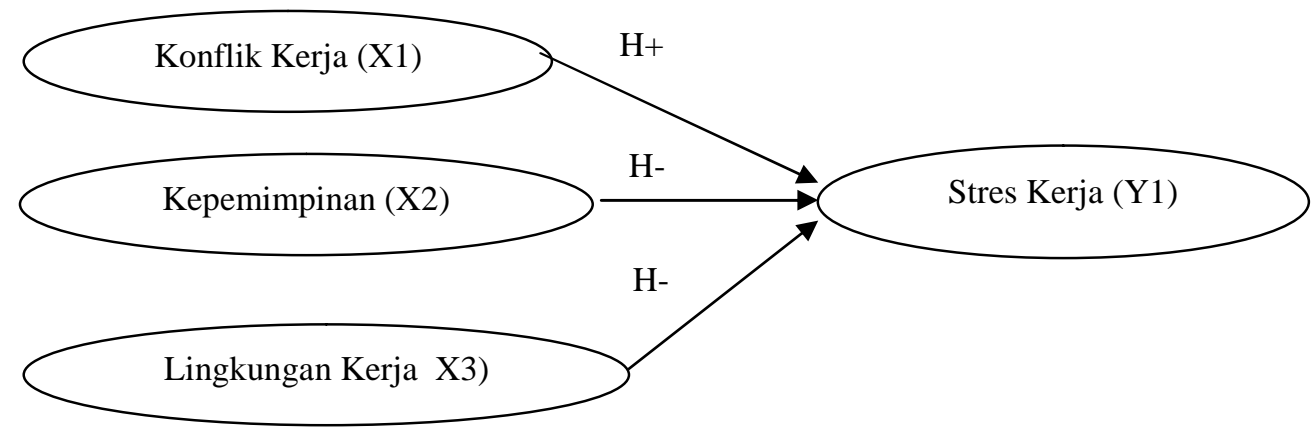

\section{Gambar 1. Kerangka Konseptual}

Sumber: Data Diolah, 2018

Berdasarkan model konseptual pada Gambar 1 dapat dijelaskan bahwa penanggulangan stres kerja sangat penting dalam suatu pekerjaan untuk mencapai kinerja terbaik. Hal itu disebabkan oleh dengan stres kerja yang tinggi menunjukkan adanya ketimpangan rasa tanggung jawab yang besar dari pegawai 
dalam menyelesaikan tugas yang diberikan kepadanya.Konflik adalah suatu hal yang bertentangan dalam diri pegawai dengan dirinya maupun rekan kerja dan lingkungannya. Konflik dapat berdampak positif dalam memicu stres kerja dari karyawan tersebut. Kepemimpinan dari seorang pemimpin dalam perusahaan sebaiknaya mencipatakan suasanya yang kondusif agar stres yang dialami pegawai dapat ditekan. Hal itu disebabkan oleh dengan kepemimpinan yang baik dapat mempengaruhi tingkat stres dari karyawan, karena pemimpin dapat memberikan motivasi kepada pegawai.

Lingkungan kerja yang kondusif perlu diperhatikan oleh pemimpin perusahaan agar para karyawan dapat bekerja dan mendapatkan hasil kerja secara maksimal. Hal tersebu dikarenakan lingkungan kerja menjadi salah satu faktor dari pemicu stres kerja pada karyawan. Lingkungan kerja yang baik akan mengurangi stres kerja pada karyawan.

\section{METODE PENELITIAN}

Penelitian ini bersifat asosiatif yang bertujuan untuk mengetahui pengaruh diantara dua variabel ataupunberlebih (Sugiyono, 2012:5). Metode penelitian memakaimetode kuantitatif berupa angka-angka hasil kuisioner para responden. Teknikpengambilan sampeldengan acak dengan simple random sampling, pengumpulan data memakai intrumen penelitian, juga analisa data memakai pengujian regresi, uji $\mathrm{F}$ dan uji t dengan maksud melakukan pengujian hipotesa yang sudah tetap jugamelakukan konfirmasi teori.Tempariset ini adalah PD. Pasar Kota Denpasar Unit Pasar Badung yang terletak di Jalan Sulawesi, Denpasar. Pemilihan lokasi ini didasarkan atas pertimbangan tersedianya data yang memadai 
untuk diteliti dan ditemukannya masalah-masalah yang mengindikasikan adannya stres kerja yang dialami oleh para pegawainya.Ruang lingkup penelitian ini adalah konflik kerja, kepemimpinan juga lingkungan kerja pada stress kerja karyawan di PD. Pasar Kota Denpasar Unit Pasar Badung. Penelitian akan difokuskan pada para pegawai yang masih aktif bekerja di PD. Pasar Kota Denpasar Unit Pasar Badung.

Objek penelitian ini terdapat total 98 karyawan di PD. Pasar Kota Denpasar Unit Pasar Badung tidak termasuk 2 pemimpin.Variabel Independen di dalam penelitian ini adalah variabel konflik kerja (X1), kepemimpinan (X2) dan lingkungan kerja (X3).Variabel dependen di dalam penelitian ini adalah stres karyawan (Y1).Ghozali (2016) menyatakan bahwa konflik kerja merupakan pertentangan antara individu, antara kelompok dan antara organisasi yang disebabkan oleh perbedaan komunikasi, tujuan dan sikap. Indikator konflik kerja yang digunakan dalam penelitian ini adalah. 1) Perbedaan dalam tujuan diukur dengan persepsi yang timbul dari masing - masing pekerja, dimana perbedaan persepi tujuan tersebut dapat menimbulkan konflik. 2) Saling ketergantungan dalam menjalankan tugas diukur dengan kecenderungan pekerja yang tidak dapat melaksanakan pekerjaannya secara mandiri. 3) Perbedaan dalam nilai dan persepsi diukur dengan perbedaan pendapat masing - masing karyawan dari segi nilai atau norma dalam melakukan pekerjaan. 4) Konflik kerja terjadi akibat kinerja dari rekan kerja yang kurang profesional. 5) Komunikasi dengan rekan kerja yang kurang harmonis. 
Menurut Malik (2015:165), kepemimpinan adalah suatu proses pemberian petunjuk dan pengaruh kepada anggota kelompok atau organisasi dalam melaksanakan tugas-tugas. Indikator kepemimpinan yang digunakan dalam penelitian ini adalah: 1) Komunikasi pemimpin, 2) Motivasi dari pemimpin, 3) Kemampuan sebagai pemimpin, 4) Ketegasan pemimpin, 5) Kekuasaan dari pemimpin. Nitisemito (2007:133), menyatakan bahwa lingkungan kerja merupakan segala sesuatu yang ada disekitar para pekerja yang dapat mempengaruhi dirinya dalam menjalankan tugas-tugas yang dibebankan. Indikator stres menurut Nawawi (2010:101) yang digunakan dalam penelitian ini adalah: 1) Penerangan yang diukur dengan intensitas cahaya yang tersedia. 2) Pertukaran udara yang diukur dengan luas ventilasi agar udara yang ada di ruangan bekerja tidak lembab. 3) Keamanan yang diukur dengan rasa percaya dan aman pekerja saat melakukan pekerjaanya. 4) Kebisingan yang diukur dengan suara yang berada di sekeliling pekerja. 5)Temperatur yang diukur dengan suhu udara dari lokasi pekerja.

Stress kerja adalah sebuah tanggapan didalam penyesuaian diri yang terpengaruh oleh perbedaan individu serta proses psikologis, sebagai konsekwensi daripada tindakan lingkungan, situasi ataupun fenomena yang terlalu banyak membuat pengadaan tuntutan psikologis serta fisik seorang.Indikator dari stress kerja yaitu:1) Beban kerja yang berlebihan, 2) Tekanan atau desakan waktu, 3) Umpan balik tentang pelaksanaan kerja yang tidak memadai, 4) Konflik antar pribadi dan antar kelompok, 5) Perbedaan antara nilai- nilai perusahaan dan karyawan. 
Data ini memberikan penjelasan lebih rinci atas penyajian data angka, sehingga akan memberikan pengertian yang lebih pengertian yang lebih dalam berbentuk info ataupun keterangan yang memiliki hubungan dengan masalah penelitian yang ingin diteliti contohnya tugas serta tanggung jawab pegawai, sejarah PD. Pasar Kota Denpasar Unit Pasar Badung dan struktur PD. Pasar Kota Denpasar Unit Pasar Badung PD. Pasar Kota Denpasar Unit Pasar Badung, data kualitatif yang diangkakan, seperti data berupa angka - angka berupa hasil kuisioner dari para responden di PD. Pasar Kota Denpasar Unit Pasar Badung.Dalam pengumpulan data ini, dilakukan wawancara kepada karyawan di PD. Pasar Kota Denpasar Unit Pasar Badung.Populasi didalam riset berikutyaitu semuapegawai di PD. Pasar Kota Denpasar Unit Pasar Badung.

Teknik analisis yang digunakan dalam penelitian ini adalah analisis regresi linier berganda bertujuan untuk mengetahui besarnya pengaruh konflik kerja, kepemimpinan, dan lingkungan kerja terhadap stres kerja pegawai. Persamaan matematis untuk hubungan yang dihipotesiskan dapat dirumuskan sebagai berikut :

$$
Y=a+b_{1} X_{1}+b_{2} X_{2}+b_{3} X_{3}+e
$$

Keterangan:

$$
\begin{array}{ll}
\mathrm{Y} & =\text { stres kerja } \\
\mathrm{a} & =\text { konstanta } \\
\mathrm{b}_{1} & =\text { koefisien regresi variabel konflik kerja } \\
\mathrm{b}_{2} & =\text { koefisien regresi variabel kepemimpinan } \\
\mathrm{b}_{3} & =\text { koefisien regresi variabel lingkungan kerja } \\
\mathrm{X}_{1} & =\text { konflik kerja } \\
\mathrm{X}_{2} & =\text { kepemimpinan } \\
\mathrm{X}_{3} & =\text { lingkungan kerja } \\
\mathrm{e} & =\text { Error. }
\end{array}
$$




\section{HASIL DAN PEMBAHASAN}

Karakteristik responden merupakan data responden yang dikumpulkan untuk mengetahui profil responden penelitian. Penelitian ini menggunakan sampel jenuh yang dimana seluruh populasi menjadi sampel, sehingga sampel dalam penelitian ini adalah 98 orang karyawan, tidak termasuk 2 pemimpin di PD. Pasar Kota Denpasar Unit Pasar Badung sebagai responden dalam penyebaran kuisioner. Berikutnya data identitas responden berdasar kepadajenis kelamin, usia,sertamasa kerjareponden. Dengan rinci karakter responden tersaji di Tabel 1 berikut:

Tabel 1.

Karakteristik Responden PD. Pasar Kota Denpasar Unit Pasar Badung

\begin{tabular}{|c|c|c|c|c|}
\hline No & Karakteristik & Klasifikasi & $\begin{array}{c}\text { Jumlah Responden } \\
\text { (orang) }\end{array}$ & $\begin{array}{c}\text { Presentase } \\
\text { Responden } \\
(\%)\end{array}$ \\
\hline \multirow{2}{*}{1} & Jenis & Laki-Laki & 58 & 58 \\
\hline & Kelamin & Perempuan & 40 & 40 \\
\hline \multicolumn{3}{|c|}{ Jumlah } & 98 & 98 \\
\hline \multirow{3}{*}{2} & & 18 - 30 tahun & 40 & 40 \\
\hline & Usia & $\begin{array}{l}31 \text { tahun } \\
\text { keatas }\end{array}$ & 58 & 58 \\
\hline & \multicolumn{2}{|c|}{ Jumlah } & 98 & 98 \\
\hline \multirow{4}{*}{3} & & $0-1$ tahun & 10 & 10 \\
\hline & Masa Kerja & $1-3$ tahun & 20 & 20 \\
\hline & & 3 tahun keatas & 68 & 68 \\
\hline & \multicolumn{2}{|c|}{ Jumlah } & 98 & 98 \\
\hline
\end{tabular}

Sumber: Data Diolah, 2018

Tabel 1menunjukkan responden dalam penelitian ini yaitu pegawai PD. Pasar Kota Denpasar Unit Pasar Badung dominan berjenis kelamin laki-laki dengan persentase 58 persen. Hal ini memberikan informasi bahwa PD. Pasar Kota Denpasar Unit Pasar Badung lebih membutuhkan karyawan laki-laki karena berkaitan dengan jenis pekerjaan yang ada. Apabila dilihat dari segi usia, 
responden sebagian besar berusia 31 tahun keatas dengan jumlah sebanyak 58 orang atau sebesar 58 persen.Penggolongan berdasarkan masa bekerja menunjukkan bahwa pegawai PD. Pasar Kota Denpasar Unit Pasar Badung paling banyak adalah yang bekerja selama 3 tahun keatas tahun adalahsejumlah 70 orang ataupun 70 persen daripada total responden, namun yang bekerja selama 1 sampai 3 tahun sejumlah 20 orang ataupun 20 persen daripada total responden dan yang bekerja selama 0 - 1 tahun sejumlah 10 orang ataupun 10 persen daripada total responden.

Tabel 2.

Rekapitulasi Hasil Uji Validitas Instrumen Penelitian

\begin{tabular}{ccccc}
\hline Variabel & Indikator & Koefisien Korelasi & Sig. (2-tailed) & Keterangan \\
\hline Konflik Kerja & $\mathrm{X}_{1.1}$ & 0,772 & 0 & Valid \\
$\left(\mathrm{X}_{1}\right)$ & $\mathrm{X}_{1.2}$ & 0,765 & 0 & Valid \\
& $\mathrm{X}_{1.3}$ & 0,797 & 0 & Valid \\
& $\mathrm{X}_{1.4}$ & 0,805 & 0 & Valid \\
& $\mathrm{X}_{1.5}$ & 0,765 & 0 & Valid \\
Kepemimpinan & $\mathrm{X}_{2.1}$ & 0,819 & 0 & Valid \\
$\left(\mathrm{X}_{2}\right)$ & $\mathrm{X}_{2.2}$ & 0,859 & 0 & Valid \\
& $\mathrm{X}_{2.3}$ & 0,816 & 0 & Valid \\
& $\mathrm{X}_{2.4}$ & 0,843 & 0 & Valid \\
Lingkungan Kerja & $\mathrm{X}_{2.5}$ & 0,823 & 0 & Valid \\
$\left(\mathrm{X}_{3}\right)$ & $\mathrm{X}_{3.1}$ & 0,843 & 0 & Valid \\
& $\mathrm{X}_{3.2}$ & 0,853 & 0 & Valid \\
& $\mathrm{X}_{3.3}$ & 0,824 & 0 & Valid \\
& $\mathrm{X}_{3.4}$ & 0,708 & 0 & Valid \\
& $\mathrm{X}_{3.5}$ & 0,707 & 0 & Valid \\
& $\mathrm{Y}_{1}$ & 0,682 & 0 & Valid \\
& $\mathrm{Y}_{2}$ & 0,802 & 0 & Valid \\
Stres kerja (Y) & $\mathrm{Y}_{3}$ & 0,808 & 0 & Valid \\
& $\mathrm{Y}_{4}$ & 0,664 & 0 & Valid \\
& $\mathrm{Y}_{5}$ & 0,782 & 0 & Valid \\
\hline
\end{tabular}

Sumber: Data Diolah, 2018

Instrumen yang valid dan reliabel diharapkan membuat penelitian menjadi valid dan reliabel. Dengan digunakannya kuesioner, maka pada penelitian ini 
perlu dilakukan uji validitas dan reliabilitas agar kuisioner layak digunakan sebagai sumber data.Menurut Sugiyono (2012) suatu instrumen dikatakan valid apabila nilai $r$ pearson correlation terhadap skor total di atas 0,30. Berikut merupakan Tabel 2 yang menyajikan hasil uji validitas instrumen penelitian.Hasil uji validitas pada Tabel 2 memberi petunjuk bahwasannya semua instrumen penelitian yang dipakaiagarmemberi ukuran variablekonflik kerja, kepemimpinan, lingkungan kerja dan stres kerja mempunyai besaran koefisien korelasi dengan nilai total semua butir pertanyaan melebihi daripada 0,30 dengan tingkat signifikan lebih kecil dari 0,05 . Hal itu memberi petunjuk bahwa item-item pertanyaandidalam instrumen penelitian itu validsertacocok dipakaimenjadi instrumen penelitian.Proses uji reliabilitas memberi petunjuk sebagaimana sebuah alat ukuranbisa kita percaya ataupunbisa kita andalkan. Pengujianberikut dilaksanakan pada instrument dengan koefisien cronbach alpha, bila melebihi dari 0,60 jadi instrument yang dipakai reliabel. Tabel 3 berikut memberikan penyajian hasil pengujian reliabilitas instrument penelitian:

Tabel 3.

Rekapitulasi Hasil Uji Reliabilitas Instrumen Penelitian

\begin{tabular}{cccc}
\hline No. & Variabel & Cronbach's Alpha & Keterangan \\
\hline $\mathbf{1}$ & Konflik Kerja $\left(\mathrm{X}_{1}\right)$ & 0,801 & Reliabel \\
$\mathbf{2}$ & Kepemimpinan $\left(\mathrm{X}_{2}\right)$ & 0,813 & Reliabel \\
$\mathbf{3}$ & Linkungan Kerja $\left(\mathrm{X}_{3}\right)$ & 0,803 & Reliabel \\
$\mathbf{4}$ & Stres kerja $(\mathrm{Y})$ & 0,791 & Reliabel \\
\hline \multicolumn{2}{l}{ Sumber: Data Diolah, 2018 }
\end{tabular}

Berdasarkan Tabel 3 diatas menunjukkan bahwa seluruh indikator pernyataan dalam variabel Konlik Kerja (X1), Kepemimpinan (X2), Lingkungan Kerja (X3) dan Stres kerja Pegawai (Y) mempunyainilai Cronbach Alpha 
melebihi dari 0,60 hingga pertanyaandi kuisioner itu reliabel.Deskripsi jawaban responden memberi penyajian penilaian responden pada tiap butir-butir pertanyaan yang diajukan didalam kuesioner.Variabel konflik kerja terukur dengan memakai5 indikator yang dibuat sesuai dengan keadaan di PD. Pasar Kota Denpasar Unit Pasar Badung. Data yang terdapat Tabel 4 memberi penampilan proporsi jawaban responden, rata-rata jawaban, serta kriteria penilaian jawaban responden bagitiap-tiap pertanyaan di variabel konflik kerja.

Tabel 4.

Deskripsi Penilaian Responden Terhadap Variabel Konflik kerja

\begin{tabular}{|c|c|c|c|c|c|c|c|}
\hline \multirow[t]{2}{*}{ Indikator } & \multicolumn{5}{|c|}{$\begin{array}{l}\text { Frekuensi Jawaban } \\
\text { Responden }\end{array}$} & \multirow[t]{2}{*}{ Rata -Rata } & \multirow[t]{2}{*}{ Keterangan } \\
\hline & 1 & 2 & 3 & 4 & 5 & & \\
\hline Perbedaan dalam tujuan $\left(\mathrm{X}_{1.1}\right)$ & 0 & 10 & 19 & 44 & 25 & 3,86 & Tinggi \\
\hline $\begin{array}{l}\text { Saling ketergantungan dalam } \\
\text { menjalankan tugas }\left(X_{1.2}\right)\end{array}$ & 0 & 6 & 27 & 41 & 24 & 3,85 & Tinggi \\
\hline $\begin{array}{l}\text { Perbedaan dalam nilai dan persepsi } \\
\left(\mathrm{X}_{1.3}\right)\end{array}$ & 2 & 8 & 25 & 30 & 33 & 3,86 & Tinggi \\
\hline $\begin{array}{l}\text { Konflik kerja terjadi akibat kinerja } \\
\text { dari rekan kerja yang kurang } \\
\text { profesional }\left(\mathrm{X}_{1.4}\right)\end{array}$ & 0 & 7 & 33 & 33 & 25 & 3,78 & Tinggi \\
\hline $\begin{array}{l}\text { Komunikasi dengan rekan kerja } \\
\text { yang kurang harmonis }\left(\mathrm{X}_{1.5}\right)\end{array}$ & 4 & 3 & 29 & 43 & 19 & 3,71 & Tinggi \\
\hline \multicolumn{6}{|c|}{ Rata-rata Skor Variabel Konflik kerja } & 3,81 & Tinggi \\
\hline
\end{tabular}

Sumber: Data Diolah, 2018

Hasil analisis deksriptif seperti yangtersaji diTabel 4 memberikan petunjuk bahwasannya variable konflik kerja dengan seluruh mendapatkan nilai rata-rata sejumlah 3,81, yang memiliki arti sebagian besar karyawan merasa bahwa pada PD. Pasar Kota Denpasar Unit Pasar Badung memiliki konflik kerja yang tinggi.Dari ketiga indikator tersebut, yang memiliki nilai rata-rata paling tinggi adalah indikator perbedaan dalam tujuan, serta indikator perbedaan dalam nilai dan persepsi, dengan nilai rata-rata sebesar 3,86. Hal tersebut disebabkan karena pada PD. Pasar Kota Denpasar Unit Pasar Badung sering terjadi perbedaan 
persepsi yang timbul dari masing - masing pekerja. Variabel kepemimpinan diukur dengan menggunakan 5 indikator yang disesuaikan dengan kondisi di PD. Pasar Kota Denpasar Unit Pasar Badung. Data yang tersaji di Tabel 5 menunjukkan proporsi jawaban responden, rata-rata jawaban, serta kriteria penilaian jawaban responden bagitiap-tiap pernyataan pada variablekepemimpinan.

Tabel 5.

Deskripsi Penilaian Responden Terhadap Variabel Kepemimpinan

\begin{tabular}{|c|c|c|c|c|c|c|c|}
\hline \multirow[t]{2}{*}{ Indikator } & \multicolumn{5}{|c|}{$\begin{array}{c}\text { Frekuensi Jawaban } \\
\text { Responden }\end{array}$} & \multirow[t]{2}{*}{ Rata -Rata } & \multirow[t]{2}{*}{ Keterangan } \\
\hline & 1 & 2 & 3 & 4 & 5 & & \\
\hline Komunikasi pemimpin (X2.1) & 2 & 29 & 36 & 26 & 5 & 3,03 & Cukup Baik \\
\hline Motivasi dari pemimpin $\left(\mathrm{X}_{2.2}\right)$ & 10 & 33 & 23 & 23 & 9 & 2,88 & Cukup Baik \\
\hline $\begin{array}{l}\text { Kemampuan sebagai pemimpin } \\
\left(\mathrm{X}_{2.3}\right)\end{array}$ & 3 & 18 & 43 & 26 & 8 & 3,18 & Cukup Baik \\
\hline Ketegasan pemimpin $\left(\mathrm{X}_{2.4}\right)$ & 9 & 22 & 37 & 16 & 14 & 3,04 & Cukup Baik \\
\hline Kekuasaan dari pemimpin $\left(\mathrm{X}_{2.5}\right)$ & 6 & 31 & 27 & 26 & 8 & 2,99 & Cukup Baik \\
\hline \multicolumn{6}{|c|}{ Rata-rata Skor Variabel Kepemimpinan } & 3,02 & Cukup Baik \\
\hline
\end{tabular}

Sumber: Data Diolah, 2018

Hasil analisis deksriptif sepertitersajidi Tabel 5 memberi petunjuk bahwasannya variable kepemimpinan dengan caraseluruhnya memberikan nilai rata-rata sejumlah 3,02, yang memiliki arti bahwasannya sebagian besar pegawai memberi penilaian kepemimpinan pada PD. Pasar Kota Denpasar Unit Pasar Badung cukup baik.Variabel lingkungan kerja diukur dengan menggunakan 5 indikator yang disesuaikan dengan kondisi lingkungan kerja pegawai di PD. Pasar Kota Denpasar Unit Pasar Badung. Data yang tersaji di Tabel 6 menunjukkan 
proporsi jawaban responden, rata-rata jawaban, serta kriteria penilaian jawaban responden bagitiap-tiap pernyataan pada variabellingkungan kerja.Hasil analisis deksriptif sebagaimana tersajidi Tabel 6 memberi petunjuk bahwasannya variable lingkungan kerja dengan cara keseluruhan mendapatkan nilai rata-rata sejumlah 3,23 , yang memiliki arti bahwasannya sebagian besar responden menilai bahwa lingkungan kerja di PD. Pasar Kota Denpasar Unit Pasar Badung cukup baik.

Tabel 6.

Deskripsi Penilaian Responden Terhadap Variabel Lingkungan kerja

\begin{tabular}{lccccccc}
\hline \multicolumn{1}{c}{ Indikator } & \multicolumn{9}{c}{$\begin{array}{c}\text { Frekuensi Jawaban } \\
\text { Responden }\end{array}$} & Rata -Rata & Keterangan \\
\cline { 2 - 6 } & $\mathbf{1}$ & $\mathbf{2}$ & $\mathbf{3}$ & $\mathbf{4}$ & $\mathbf{5}$ & & Baik \\
\hline Penerangan $\left(\mathrm{X}_{3.1}\right)$ & 2 & 15 & 28 & 39 & 14 & 3,49 & Cukup Baik \\
Pertukaran udara $\left(\mathrm{X}_{3.2}\right)$ & 6 & 19 & 42 & 16 & 15 & 3,15 & Cukup Baik \\
Keamanan $\left(\mathrm{X}_{3.3}\right)$ & 3 & 29 & 38 & 16 & 12 & 3,05 & Cukup Baik \\
Kebisingan $\left(\mathrm{X}_{3.4}\right)$ & 3 & 42 & 16 & 15 & 22 & 3,11 & Cukup Baik \\
Temperatur $\left(\mathrm{X}_{3.5}\right)$ & 2 & 24 & 29 & 24 & 19 & 3,35 & Cukup Baik \\
\hline \multicolumn{10}{c}{ Rata-rata Skor Variabel Lingkungan kerja } \\
\hline Sumber: Data Diolah, 2018
\end{tabular}

Variabel Stres kerja diukur dengan menggunakan 5 indikator yang disesuaikan dengan kondisi stres kerja pegawai di PD. Pasar Kota Denpasar Unit Pasar Badung. Data yang tersaji di Tabel 7 menunjukkan proporsi jawaban responden, rata-rata jawaban, serta kriteria penilaian jawaban responden bagitiaptiap pernyataan di variablestres kerja.

Tabel 7.

Deskripsi Penilaian Responden Terhadap Variabel Stres kerja

\begin{tabular}{|c|c|c|c|c|c|c|c|}
\hline \multirow[t]{2}{*}{ Indikator } & \multicolumn{5}{|c|}{$\begin{array}{c}\text { Frekuensi Jawaban } \\
\text { Responden }\end{array}$} & \multirow[t]{2}{*}{ Rata -Rata } & \multirow[t]{2}{*}{ Keterangan } \\
\hline & 1 & 2 & 3 & 4 & 5 & & \\
\hline Beban kerja yang berlebihan $\left(\mathrm{Y}_{1}\right)$ & 0 & 8 & 29 & 41 & 20 & 3,74 & Tinggi \\
\hline Tekanan atau desakan waktu $\left(\mathrm{Y}_{2}\right)$ & 2 & 4 & 17 & 42 & 33 & 4,02 & Tinggi \\
\hline $\begin{array}{l}\text { Umpan balik tentang pelaksanaan } \\
\text { kerja yang tidak memadai }\left(\mathrm{Y}_{3}\right)\end{array}$ & 2 & 10 & 24 & 38 & 24 & 3,73 & Tinggi \\
\hline $\begin{array}{l}\text { Konflik antar pribadi dan antar } \\
\text { kelompok }\left(\mathrm{Y}_{4}\right)\end{array}$ & 2 & 6 & 32 & 36 & 22 & 3,71 & Tinggi \\
\hline $\begin{array}{l}\text { Perbedaan antara nilai- nilai } \\
\text { perusahaan dan karyawan }\left(\mathrm{Y}_{5}\right)\end{array}$ & 0 & 4 & 21 & 53 & 20 & 3,91 & Tinggi \\
\hline \multicolumn{6}{|c|}{ Rata-rata Skor Variabel Stres kerja } & 3,82 & Tinggi \\
\hline
\end{tabular}


Sumber: Data Diolah, 2018

Analisis deksriptif sepertitersajidi Tabel 7 memberi petunjuk bahwasannya variable stres kerja denganseluruh mendapatkan nilai rata-rata sejumlah 3,82 , yang memiliki arti bahwasannya sebagian besar karyawan pada PD. Pasar Kota Denpasar Unit Pasar Badung memiliki stres kerja yang tinggi.Dari lima indikator tersebut, yang memiliki nilai paling tinggi adalah indikator tekanan atau desakan waktu.Sesuai dengan hasil memberi hitungan dengan memakai program SPSS for windows jadi diperoleh persamaan regresi linear berganda adalah:

Tabel 8.

Hasil Analisis Regresi Linear Berganda

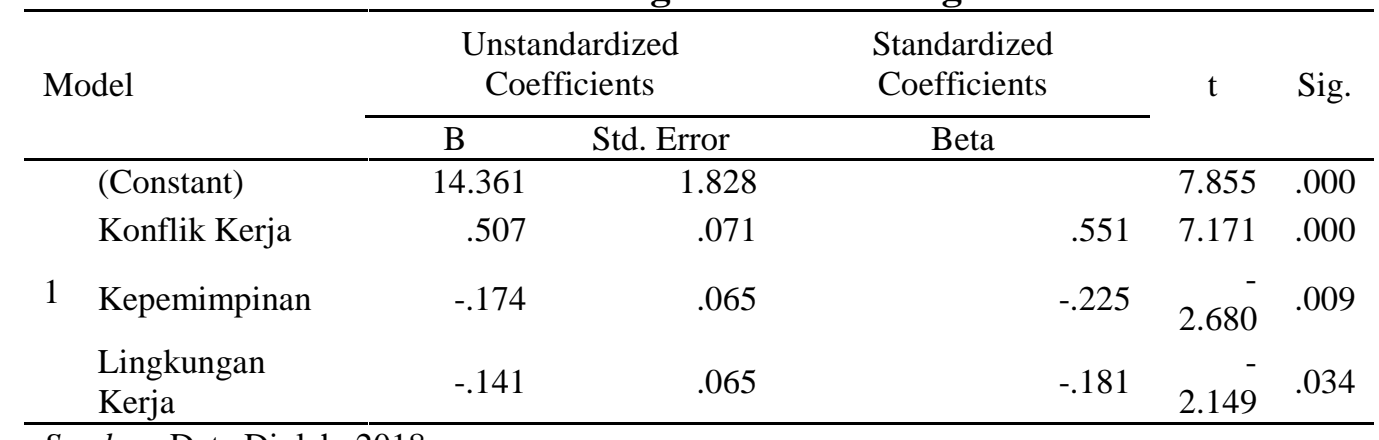

Sumber: Data Diolah, 2018

Berdasar kepada hasil analisis regresi linier berganda yang tersajidiTabel 8 , jadibisamembentuk persamaan regresi sebagai berikut:

$$
Y=14,361+0,507 X_{1}-0,174 X_{2}-0,141 X_{3}
$$

Persamaan regresi tersebut dapat dijelaskan sebagai berikut: 1) Nilai konstanta $(\boldsymbol{u})$, memiliki arti apabila variabel konflik kerja $\left(\mathrm{X}_{1}\right)$, kepemimpinan $\left(\mathrm{X}_{2}\right)$, dan lingkungan kerja $\left(\mathrm{X}_{3}\right)$, tetap atau sama dengan nol, maka stres kerja pegawai pada PD. Pasar Kota Denpasar Unit Pasar Badung (Y) tidak meningkat. 2) $b_{1}=0,507$ artinya apabila konflik kerja meningkat sedangkan kepemimpinan dan lingkungan kerja tetap, maka stres kerja pegawai akan meningkat.3) $b_{2}=-$ 
0,174 artinya apabila kepemimpinan meningkat sedangkan konflik kerja dan lingkungan kerja tetap, maka stres kerja pegawai akan menurun sebesar. 4) $b_{3}=-$ 0,141 artinya apabila lingkungan kerja menjadi lebih baik sedangkan konflik kerja dan kepemimpinan tetap, maka stres kerja pegawai akan menurun.

Nilai Kolmogorov Sminarnov (K-S) sejumlah 0,719, tapi nilai Asymp. Sig. (2-tailed) sejumlah 0,679. Hasil itu memberi kepadaindikator bahwas model persamaan regresi itumempunyaidistribusi normal karena nilai Asymp. Sig. (2tailed) lebih besar dari nilai alpha 0,05 atau Asymp.Sig > 0,05.Nilai toleranceserta VIF daripada semua variable itu menunjukkan bahwa nilai tolerancebagi tiap-tiap variable lebih besar dari $10 \%$ dan nilai VIF lebih kecil dari 10 yang mempunyai arti model persamaan regresi bebas daripada multikolinearitas. Nilai Signifikansi dari variable Konlik Kerja (X1) sejumlah0,781, Kepemimpinan (X2) sejumlah 0,213 serta Lingkungan Kerja (X3) sejumlah 0,086. Nilai tersebut lebih besar dari 0,05 yang berarti tidak terdapat pengaruh antara variabel bebas terhadap absolute residual. Dengan demikian, model yang dibuat bebas gejala heteroskedastisitas.

Proses uji hipotesis yang diajukan akanlah memakai uji F dengan memakai program SPSS versi 17.0 for windows dengan memiliki tujuan agar melakukan uji koefisien yang sudah didapatdidalam penghitungan sebelum ini. Untuk proses uji hipotesa yang diajukan dipakai uji F. Analisa ini mempunyaitujuan agar melakukan pengujian koefisien yang sudah didapatkandidalam penghitungan sebelumnya.Hasil pengujian $\mathrm{F}$ (Ftest) memberikan petunjuk bahwasannya nilai $\mathrm{F}$ Hitung senilai25,545 dengan besaran signifikansi $\mathrm{P}$ value 0,000 yang lebih kecil dari $\alpha=0,05$, ini memiliki arti model yang dipakai diriset berikutmenjadi layak. 
Tabel 9.

Hasil Uji Simultan (F-test)

\begin{tabular}{|c|c|c|c|c|c|c|}
\hline & Model & Sum of Squares & Df & $\begin{array}{l}\text { Mean } \\
\text { Square }\end{array}$ & $\mathrm{F}$ & Sig. \\
\hline \multirow{3}{*}{1} & Regression & 497.856 & 3 & 165.952 & 25.545 & $.000^{\mathrm{a}}$ \\
\hline & Residual & 610.675 & 94 & 6.497 & & \\
\hline & Total & 1.108 .531 & 97 & & & \\
\hline
\end{tabular}

Hasil tersebut memberi makna bahwasannya semua variable independentbisa melakukan prediksi ataupun memberi penjelasan kejadian stress kerja pegawai pada PD. Pasar Kota Denpasar Unit Pasar Badung. Hal ini berarti model dapat digunakan untuk analisa lebih lanjut atau dengan kata lain ada pengaruh secara simultan dari variabel konflik kerja, kepemimpinan, serta lingkungan kerja pada stress kerja karyawan diPD. Pasar Kota Denpasar Unit Pasar Badung.Koefisien Determinasi $\left(\mathrm{R}^{2}\right)$ dipakaiagar memberitahusertamemberi ukuran kemampuan model didalam penerangan variasi variable independen. Peneliti memakai nilai adjusted $\mathrm{R}^{2}$ diwaktu memberi evaluasi yang dimana model regresi terbaik, dikarenakan tidak seperti $\mathrm{R}^{2}$, nilai adjusted $\mathrm{R}^{2}$ dapat naik atau turun bila sebuah variable bebas ditambah kedalam model. Hasil uji koefisien determinasi didalam penelitian tersebutbisa terlihat di Tabel 10 sebagai berikut:

Tabel 10.

Hasil Uji Koefisien Determinasi

\begin{tabular}{|c|c|c|c|c|}
\hline Model & $\mathrm{R}$ & R Square & Adjusted R Square & Std. Error of the Estimate \\
\hline 1 & $.670^{\mathrm{a}}$ & .449 & .432 & 2.549 \\
\hline
\end{tabular}

Hasil uji pada Tabel 10 menunjukkan hasil dimana diperoleh besarnya nilai adjusted $\mathrm{R}^{2}$ (koefisien determinasi yang telah disesuaikan) adalah sebesar 0,432. Ini berarti variasi stress kerja karyawandiPD. Pasar Kota Denpasar Unit Pasar 
Badung dapat dipengaruhi secara signifikan oleh variabel konflik kerja $\left(\mathrm{X}_{1}\right)$, kepemimpinan $\left(\mathrm{X}_{2}\right)$, dan lingkungan kerja $\left(\mathrm{X}_{3}\right)$, sebesar 43,2 persen sedangkan sisanya sejumlah 56,8 persen sisanya diberikan penjelasan oleh faktor-faktor lainnya yang tak dijelaskan didalam model penelitian berikut.Berdasar kepada hasil analisis pengaruh konflik kerja pada stres kerja didapatkan nilai signifikasi sebesar 0,000 dengan nilai koefisien beta 0,507. Nilai Signifikansi 0,000 $<0,05$ memberikan indikasi bahwasannya $\mathrm{H}_{0}$ ditolak serta $\mathrm{H}_{1}$ diterima. Hasil ini memiliki arti bahwasannyakonflik kerja memiliki pengaruh positif serta signifikan padastres kerja karyawan di PD. Pasar Kota Denpasar Unit Pasar Badung.

Berdasar kepada hasil analisis pengaruh Kepemimpinan pada Stres kerja didapatkan nilai Signifikansi sebesar 0,009 dengan nilai koefisien beta -0,174. Nilai Signifikansi $0,009<0,05$ memberikan indikasi bahwasannya $\mathrm{H}_{0}$ ditolak serta $\mathrm{H}_{2}$ diterima. Hasil ini memiliki arti bahwasannya kepemimpinanmemiliki pengaruh negatif serta signifikan terhadap stres kerja karyawan di PD. Pasar Kota Denpasar Unit Pasar Badung.Berdasarkan hasil analisis pengaruh lingkungan kerja terhadap stres kerja diperoleh nilai signifikansi sebesar 0,034 dengan nilai koefisien beta sebesar $-0,141$. Nilai signifikansi $0,034<0,050$ mengindikasikan bahwa $\mathrm{H}_{0}$ ditolak dan $\mathrm{H}_{3}$ diterima. Hasil ini mempunyai arti bahwa Lingkungan kerja berpengaruh negatif dan signifikan terhadap Stres kerja pegawai di PD. Pasar Kota Denpasar Unit Pasar Badung.

Perselisihan atau konflik merupakan suatu yang tidak dapat dihindari. Konflik dapat berpengaruh positif dan negatif. Hasil analisis dalam penelitian ini menunjukkan bahwa konflik kerja berpengaruh positif dan signifikan terhadap 
stres kerja pegawai.Semakin tinggi konflik kerja yang dialami pegawai maka akan berpengaruh pada semakin meningkatnya stres kerja pegawaidi PD. Pasar Kota Denpasar Unit Pasar Badung. Begitu pula sebaliknya, apabila pegawai tidak mengalami konflik pada saat bekerja, maka stres kerja pegawai di PD. Pasar Kota Denpasar Unit Pasar Badung akan semakin berkurang.

Penelitian berikut mendukung beberapa hasil penelitian sebelumnya serta konsisten dengan hasil penelitian yang dilaksanakan oleh Adekunle (2014), Harlock (2013), Anuari dkk. (2017), Han dan Netra (2014) dan Hwang (2014) yang menyatakan bahwa terdapat pengaruh yang positif dan signifikan antara konflik kerja terhadap stres kerja pegawai. Hal ini berarti bahwa konflik yang tidak dikelola dengan baik dan dibiarkan terus meneurs akan menyebabkan stres pada pegawai.

Salah satu faktor yang mempengaruhi stres kerja karyawan adalah kepemimpinan dalam organisasi. Kepemimpinan merupakan salah satu penentu arah dalam perkembangan organisasi dimana gaya kepemimpinan seseorang dalam mengelola organisasi mempunyai pengaruh terhadap stres kerja. Pemimpin yang menuntut karyawan untuk melakukan tugas dalam waktu yang singkat, pengawasan yang ketat dan tekanan yang kurang realistis dapat menimbulkan stres kerja pada karyawan (Robbins, 2014). Hasil analisis dalam penelitian ini menunjukkan bahwa kepemimpinan berpengaruh negatif dan signifikan terhadap stres kerja.Semakin baik gaya kepemimpinan pada PD. Pasar Kota Denpasar Unit Pasar Badung maka akan berpengaruh pada semakin berkurangnya stres kerja pegawai diPD. Pasar Kota Denpasar Unit Pasar Badung. Begitu pula sebaliknya, 
semakin buruk tingkat kepemimpinan pada Pada PD. Pasar Kota Denpasar Unit Pasar Badung maka akan berpengaruh pada semakin meningkatnya stres kerja pegawai.

Penelitian berikut memberi dukungan beberapa hasil penelitian sebelumnya serta konsisten dengan hasil penelitian yang dilaksanakan oleh Danny (2013), Cheng (2013), Campbell (2015) dan Gordon (2014) yang sama - sama mejelaskan bahwa terdapat pengaruh yang negatif dan signifikan antara kepemimpinan terhadap stres kerja pegawai.

Lingkungan kerja dimana semua pegawai melakukan aktivitasnya baik didalam kantor maupun diluar kantor, sangat penting untuk diperhatikan oleh pihak perusahaan. Hal itu karena salah satu penyebab dari stres kerja adalah lingkungan yang tidak nyaman. Hasil analisis dalam penelitian ini menunjukkan bahwa lingkungan kerja berpengaruh negatif dan signifikan terhadap stres kerja.Semakin baik lingkungan kerja pada PD. Pasar Kota Denpasar Unit Pasar Badung maka akan berpengaruh pada semakin berkurangnya stres kerja pegawai diPD. Pasar Kota Denpasar Unit Pasar Badung. Begitu pula sebaliknya, semakin buruk dan tidak nyaman lingkungan kerja pada Pada PD. Pasar Kota Denpasar Unit Pasar Badung maka akan berpengaruh pada semakin meningkatnya stres kerja pegawai.

Penelitian ini mendukung beberapa hasil penelitian sebelumnya dan konsisten dengan hasil penelitian yang dilakukan oleh Christanto (2014), Chuanbao (2015), Rizki dkk. (2016), Mangkuprawira (2014) dan Bagyono 
(2016)yang sama-sama mejelaskan bahwa terdapat pengaruh yang negatif dan signifikan antara lingkungan kerja terhadap stres kerja pegawai.

Hasil penelitian ini memiliki implikasi teoritis dan praktis. Secara teoritis, hasil penelitian ini menunjukkan bahwa konflik kerja berpengaruh positif dan signifikan terhadap stres kerja, kepemimpinan dan lingkungan kerja berpengaruh negatif dan signifikan terhadap stres kerja. Hasil penelitian ini memberikan dukungan empiris dan dinyatakan memperkuat hasil-hasil studi penelitian terdahulu. Secara praktis, penelitian ini diharapkan memberikan manfaat bagi pimpinan dan pegawai PD. Pasar Kota Denpasar Unit Pasar Badung. Pimpinan dan pegawai dalam mengahadapi konflik kerja diharapkan dapat mengatasi perbedaan nilai dan persepsi dari perusahaan dengan jelas agar dapat menurunkan stres kerja pegawai pada PD. Pasar Kota Denpasar Unit Pasar Badung. Pimpinan pada PD. Pasar Kota Denpasar Unit Pasar Badung memiliki kualitas sebagai pemimpin dalam menjalankan roda perusahaan agar menurunkan stres kerja. Manajemen PD. Pasar Kota Denpasar Unit Pasar Badung agar selalu menjaga dan memperhatikan kualitas dari penerangan ditempat kerja agar dapat menurunkan stres kerja pegawai.

\section{SIMPULAN DAN SARAN}

Berdasarkan hasil penelitian, maka dapat disimpulkan sebagai berikut: 1)Konflik kerja berpengaruh positif dan signifikan terhadap stres kerja pegawai pada PD. Pasar Kota Denpasar Unit Pasar Badung. Artinya semakin tinggi konflik kerja yang dialami pegawai maka akan berpengaruh pada semakin meningkatnya

stres kerja pegawaidi PD. Pasar Kota Denpasar Unit Pasar Badung. 2) 
Kepemimpinan berpengaruh negatif dan signifikan terhadap stres kerja pegawai pada PD. Pasar Kota Denpasar Unit Pasar Badung.Artinya, semakin baik gaya kepemimpinan pada PD. Pasar Kota Denpasar Unit Pasar Badung maka akan berpengaruh pada semakin berkurangnya stres kerja pegawai diPD. Pasar Kota Denpasar Unit Pasar Badung. 3) Lingkungan kerja berpengaruh negatif dan signifikan terhadap stres kerja pegawai pada PD. Pasar Kota Denpasar Unit Pasar Badung. Artinya, semakin baik lingkungan kerja pada PD. Pasar Kota Denpasar Unit Pasar Badung maka akan berpengaruh pada semakin berkurangnya stres kerja pegawai diPD. Pasar Kota Denpasar Unit Pasar Badung.

Berdasarkan keterbatasan yang terdapat dalam penelitian ini, maka penelti mengajukan saran antara lain: 1) Pemimpin di PD. Pasar Kota Denpasar Unit Pasar Badung hendaknya menyamakan persepsi tujuan dan nilai antar pegawai.Dengan disamakannya persepsi tujuan dan nilai dapat mwnghindari konflik kerja dan menurunkan stres kerja pegawai di PD. Pasar Kota Denpasar Unit Pasar Badung. 2) Pimpinan PD. Pasar Kota Denpasar Unit Pasar Badung hendaknya memberikan motivasi finansial dan non finansial yang baik kepada pegawai berupa tunjungan dan inspirasi untuk mencapai tujuan bersama melalui kerjasama antar pemimpin dan pegawai, sehingga dapat menurunkan stres kerja. Pihak manajemen juga harus meningkatkan keamanan agar pegawai merasa aman saat bekerja. 3) Hasil dari penelitian ini diharapkan mampu mendorong penelitipeneliti selanjutnya untuk mengamati faktor-faktor lain yang dapat mempengaruhi stres kerja selain konflik kerja, kepemimpinan, dan lingkungan kerja. Penelitian selanjutnya juga diharapkan dapat menambah jumlah sampel penelitian serta 
memperluas wilayah sampel penelitian, dan dapat melakukan penelitian pada beberapa lembaga lainnya di Provinsi Bali sehingga nanti hasilnya dapat digeneralisasikan untuk lingkup yang lebih luas.

\section{REFERENSI}

Adekunle, Adetola. (2014). Impact of Employee Stress on Operational Risk Management. Journal of The Business School University of Gloucestershire. 1(1), 6-15

Anuari, Rizqi., Hamidah, Nayai Utami., dan Arik Prasetya. (2017). Pengaruh Konflik Kerja Terhadap Stres Kerja Dan Motivasi Kerja Serta Dampaknya Terhadap Komitmen Organisasional (Studi pada Karyawan PT Pelabuhan Indonesia III (Persero) Kantor Pusat). Jurnal Administrasi Bisnis (JAB). 42(1), 102-109

Bagyono, Muhammad. (2016). Penguasan Manajemen Stres Kerja Karyawan di Hotel Bintang Lima. PT. Gramedia: Jakarta.

Campbell, Kelley. 2015. Convenience Work Environment, Leaderhsip Work Programs, and Employee Stress Level. Journal of Walden Dissertations and Doctoral Studies.5(1), 19-42

Cheng Siew Yee, Gee Oon Kei, Law Voon Ee, Ng Sze Wee and Tai Mun Ying . (2013). The Effect Leadership And Work Environment Provided By Organization Towards Employee Stress Behaviour In Hotel Industry. A research project of Bachelor Of Business Administration.18(1),1-161

Christanto, Freddie Yeremia dan Santoso, Thomas. (2014). Analisis Pelatihan Dan Lingkungan Kerja Di PT Wahana Kosmetika Indonesia. Jurnal Program Manajemen Bisnis Universitas Petra. 2(2), 1-10

Chuanbao Yu, Haiyan Sun and Baozhen Han. (2015). Design and implementation of Chinese Leadership and Work Environment Towards To Employee Stress Management. International Conference on Education Technology, Management and Humanities Science. 7(1), 1-9

Danny, Albert. (2013). Kepemimpinan Dan Lingkungan Kerja Terhadap Stres Kerja Pada Restoran A\&W Di City Of Tomorrow Surabaya. Jurnal Program Manajemen Bisnis.1(1),1-8

Dunette, Dunson. (2015). How To Increase Work Capability Based on Skill. PT. Era Intermedia : Jakarta.

Gehee, Sinea. (2013). The Best Way to Avoid Conflict For The New Employee. PT. Java Books : Jakarta. 
Ghozali. (2016). Metode Penelitian. Penerbit Gramedia : Jakarta.

Gordon, Michael. (2014). Leadership and Work Enviroment Arrangment to Indicate The Employee Productivity. PT. Gramedia : Jakarta.

Han, Che., dan I Gusti Salit Ketut Netra. (2014). Pengaruh Konflik Terhadap Stres Kerja Dan Kepuasan Kerja Karyawan. E-Jurnal Manajemen Universitas Udayana. 3(8), 2150-2166

Harlock, Savir. (2013). Development of The Company Human Resource To Avoid Conflict. PT. Gramedia : Jakarta.

Hasibuan. (2012). Pengembangan Sumber Daya Manusia ManajemenPelatihan Ketenagakerjaan. Jakarta: PT. Bumi Aksara.

Hwang, Xi (2014). Development of Employee Conflict Management To Survive on Today Business. CV. Tinta Bhuana : Yogjakarta

Malik. (2015). Manajemen Personalia dan Sumber Daya Manusia. Yogyakarta: BPFE.

Mangkuprawira, Muhammad. (2014). Kepemimpinan dan Lingkungan Karakter Para Karyawan. PT. Grasindo : Jakarta.

Nazir. (2003). Metode Penelitian, Cetakan Keempat. Jakarta : Ghalia Indonesia

Noordiansah, Pasih. (2016). Pengaruh Lingkungan Kerja Terhadap Stres Kerja Perawat Studi Pada Rumah Sakit Muhammadiyah Jombang. Jurnal Ilmiah Mahasiswa FEB Universitas Brawijaya. 1(2), 1-12

Rizki, Muhammad., Djamhur Hamid, dan Yuniadi Mayowan. (2016). Pengaruh Lingkungan Kerja Terhadap Stres Kerja Karyawan (Studi Pada Karyawan PT PLN (Persero) Distribusi Jawa Timur Area Pelayanan Malang). Jurnal Administrasi Bisnis (JAB). 41(1), 9-15

Sugiyono. (2012). Metode Penelitian. Bandung: CV. Alfabeta 